\title{
New uracil analogs as downregulators of $A B C$ transporters in 5-fluorouracil-resistant human leukemia HL-60 cell line
}

\author{
Angelika Długosz-Pokorska ${ }^{1} \cdot$ Marlena Pięta ${ }^{2} \cdot$ Tomasz Janecki $^{2}$ Anna Janecka ${ }^{1}[$
}

Received: 5 July 2019 / Accepted: 31 July 2019 / Published online: 18 November 2019

(c) The Author(s) 2019

\begin{abstract}
Overexpression of ATP-binding cassette (ABC) transporters causing multidrug resistance (MDR) in cancer cells is one of the major obstacles in cancer chemotherapy. The 5-FU resistant subclone (HL-60/5FU) of the human HL-60 promyelocytic leukemia cell line was selected by the conventional method of continuous exposure of the cells to the drug up to $0.08 \mathrm{mmol} / \mathrm{L}$ concentration. HL-60/5FU cells exhibited six-fold enhanced resistance to 5-FU than HL-60 cells. RT-PCR and ELISA assay showed significant overexpression of MDR-related ABC transporters, ABCB1, ABCG2 but especially ABCC1 in the HL60/5FU as compared with the parental cell line. Three novel synthetic 5-methylidenedihydrouracil analogs, U-236, U-332 and U-359, selected as highly cytotoxic for HL-60 cells in MTT test, showed similar cytotoxicity in the resistant cell line. When co-incubated with 5-FU, these analogs were found to down-regulate the expression of all three transporters. However, the most pronounced effect was caused by U-332 which almost completely abolished ABCC1 expression in the resistant HL-60/5FU cells. Additionally, U-332 inhibited the activity of ATPase, an enzyme which catalyzes hydrolysis of ATP, providing energy to efflux drugs from the cells through the cellular membranes. Taken together, the obtained data suggest that acquired 5-FU resistance in $\mathrm{HL}-60 / 5 \mathrm{FU}$ cells results from overexpression of $\mathrm{ABCC} 1$ and that targeting $\mathrm{ABCC} 1$ expression could be a potential approach to re-sensitize resistant leukemia cells to 5-FU. The synthetic uracil analog U-332, which can potently down-regulate $\mathrm{ABC}$ transporter expression and therefore disturb drug efflux, can be considered an efficient $\mathrm{ABCC} 1$ regulator in cancer cells.
\end{abstract}

Keywords MDR phenotype - ABCB1 - ABCC1 - ABCG2 - ATP-ase activity

\section{Introduction}

Acute myeloid leukemia (AML), characterized as a heterogeneous clonal disorder of hematopoietic progenitor cells, is known to be a frequent cause of cancer-related deaths [1]. Therapies offered for patients with AML are not very successful and survival after relapse remains poor. The main reason of this poor therapeutic outcome is the resistance to anticancer drugs [2]. Neoplastic cells can develop several mechanisms of multidrug resistance (MDR), such as DNA mutations, metabolic changes leading to drug degradation

Anna Janecka

anna.janecka@umed.lodz.pl

1 Department of Biomolecular Chemistry, Faculty of Medicine, Medical University of Lodz, Mazowiecka 6/8, Lodz, Poland

2 Faculty of Chemistry, Institute of Organic Chemistry, Lodz University of Technology, Lodz, Poland or drug target alteration, inhibition of cell death and, quite often, overexpression of ATP-binding cassette (ABC) transporters [3-5].

The $\mathrm{ABC}$ transporter family consists of transmembrane proteins that use the energy from ATP hydrolysis to efflux various potentially dangerous compounds of diverse structure across a cell membrane [3-5]. While such efflux is a normal physiological process, it is also a known mechanism of drug resistance in cancer cells. Up to now 49 ABC transporters have been identified in human cells [6]. Among them $P$-glycoprotein (ABCB1), multidrug resistance-associated protein 1 (ABCC1) and breast cancer resistance protein (ABCG2) are three best known transmembrane proteins from the $A B C$ family that in many cases reduce the cellular uptake of drugs into cancer cells, defending them from medical interventions [7, 8].

In leukemic cells, both $\mathrm{ABCB} 1$ and $\mathrm{ABCG} 2$ are the most extensively characterized $\mathrm{ABC}$ transporters causing MDR [9-11]. However, many studies demonstrated that ABCC1 
may also be responsible for anticancer drug insensitivity in leukemic cells [12-15]. ABCC1 can confer resistance to many commonly used anticancer drugs, including 5-fluorouracil (5-FU) [16, 17]. 5-FU, was the first synthetic analog of the pyrimidine base uracil which showed pharmacological activity [18-21]. At the molecular level, 5-FU is an antineoplastic antimetabolite that interferes with DNA synthesis by blocking the thymidylate synthase-catalyzed conversion of deoxyuridylic acid to thymidylic acid [18]. In the in vitro studies 5-FU was shown to induce apoptosis and cell cycle arrest and inhibit proliferation in numerous cancer cell lines [19-21]. Since 1957 5-FU has been a widely administered anticancer drug and it still plays an important role in the treatment of several cancers, including colon and breast cancers [22]. But despite its many advantages, clinical usefulness of 5-FU today has been greatly limited due to drug resistance. Therefore, novel drug candidates for chemotherapy and reversal of resistance are urgently needed. In the search for better anticancer drugs, uracil can serve as a useful tool for manipulating lipophilicity, polarity, and hydrogen bonding capacity of molecules, which may result in improved pharmacological, pharmacokinetic, toxicologi$\mathrm{cal}$, and physicochemical properties of such agents [23, 24]. To this end, great attention has been given to 5-methylidenedihydrouracils which contain a conjugated exo-methylidene double bond incorporated onto the dihydrouracyl ring [25] (Fig. 1). Such structures, which may act as pyrimidine antimetabolites and/or as alkylating agents, raise the possibility of enhanced cytotoxic activity. Alkylation can decrease the activity of glutathione $S$-transferase (GST), the enzyme whose high level is observed in various types of cancer cells.<smiles>O=c1cc[nH]c(=O)[nH]1</smiles>

uracil<smiles>O=c1[nH]cc(F)c(=O)[nH]1</smiles>

5-fluorouracil<smiles>[R]C1NC(=O)NC(=O)C1=C</smiles>

5-methylidenedihydrouracil

Fig. 1 Structures of biologically active compounds containing uracil skeleton

Fig. 2 Chemical structures of novel 5-methylidenedihydrouracils used in this study
Moreover, GST in some tumor cells is typically associated with elevated level of glutathione (GSH), one of the major factors contributing to MDR by reducing reactive oxygen species (ROS) and disturbing DNA repair processes [26, 27]. Modulation of GST activity is therefore considered a potentially useful approach to overcome resistance to certain anticancer drugs [27].

Continuing the search for novel anticancer compounds containing an exo-cyclic methylidene group conjugated with a carbonyl function, we have synthesized a series of 1,3-disubstituted or 1,3,6-trisubstituted 5-methylidenedihydrouracils [28], which all showed significant cytotoxicity against HL-60 leukemia cells (unpublished data). Three most potent analogs from this series, designated U-236, U-332 and U-359 (Fig. 2) have been chosen for further biological evaluation as possible inhibitors/downregulators of the major $\mathrm{ABC}$ transporters, $\mathrm{ABCB} 1, \mathrm{ABCC} 1$ and $\mathrm{ABCG} 2$, using 5-FU-selected multidrug-resistant human leukemia HL-60 cell line.

\section{Materials and methods}

\section{Synthetic uracil analogs}

Synthesis of 5-methylidenedihydrouracils U-236, U-332 and U-359 was performed using Horner-Wadsworth-Emmons methodology according to the described procedure. The purity of compounds established by NMR and analytical HPLC was over 96\% [28].

\section{Cell culture}

The promyelocytic leukemia cell line (HL-60) was purchased from the European Collection of Cell Cultures (ECACC). HL-60 cells were cultured in RPMI 1640 plus GlutaMax I medium (Invitrogen, Grand Island, NY, USA), supplemented with antibiotics $(100 \mathrm{U} / \mathrm{mL}$ penicillin and $100 \mu \mathrm{g} / \mathrm{mL}$ streptomycin) and $10 \%$ fetal bovine serum (FBS). Cells were maintained at $37{ }^{\circ} \mathrm{C}$ in a $5 \% \mathrm{CO}_{2}$ atmosphere and were grown until $80 \%$ confluence. Cells not treated with the tested compounds were used as control. Both, untreated<smiles>C=C1C(=O)N(c2ccc(Br)cc2)C(=O)N(CC)C1c1ccccc1</smiles>

$\mathrm{U}-332$<smiles>C=C1C(=O)N(c2ccc(OC)cc2)C(=O)N(CC)C1c1ccccc1</smiles>

U-359 
cells and cells incubated with the analogs were cultured in the same way.

\section{Selection of 5-FU-resistant HL-60 cells (HL-60/5FU)}

Selection of 5-FU-resistant cells was performed by the 3 months exposure of HL-60 cells to increasing 5-FU concentrations $(0.001-0.08 \mathrm{mmol} / \mathrm{L})$.

MTT-based toxicity assay was used to analyze the metabolically active cells. When the proliferation was similar to parental HL-60 cells, the concentration of 5-FU was increased. The procedure was repeated until the cells were able to tolerate up to $0.08 \mathrm{mmol} / \mathrm{L}$ of 5-FU. 5-FU-resistant HL-60 cells, designated HL-60/5FU, were than evaluated in other tests.

\section{MTT-based toxicity assay}

The cytotoxicity of novel analogs was determined by MTT colorimetric assay which measures the activity of cellular dehydrogenases [29].

Briefly, cancer cells $\left(10^{4} /\right.$ well $)$ were seeded into 24-well plates (in $100 \mu \mathrm{L}$ ) and left for $24 \mathrm{~h}$. Various concentrations of the tested compounds were added and after another $24 \mathrm{~h}$ the MTT solution was added to each well. The plates were incubated for $2 \mathrm{~h}$ at $37^{\circ} \mathrm{C}$, then the medium was removed and $100 \mu \mathrm{L}$ of dimethyl sulfoxide (DMSO) was added to each well. The absorbance of the blue formazone product was measured at $560 \mathrm{~nm}$ using the iMark Bio-Rad microplate reader (Hercules, CA, USA).

\section{Quantitative real-time PCR assay}

The mRNA levels of ABC transporter genes were analyzed by quantitative RT-PCR. Briefly, the HL-60 and HL-60/5FU cells were seeded on the 6-well plates at the appropriate cell density $\left(4.0 \times 10^{5}\right.$ cells/well $)$ and left to grow. Then, the cells were treated with the tested compounds or co-incubated with the tested compounds and 5-FU (at $\mathrm{IC}_{50}$ concentration each) for $24 \mathrm{~h}$. The effects of the combination treatment were compared with those produced by the tested compounds alone.

Total RNA was extracted using the Total RNA Mini Kit (A\&A Biotechnology, Gdynia, Poland) according to the manufacturer protocol. The concentration of RNA was measured using sensitive single-tube fluorimeter for fluorescence-based quantitation of nucleic acids and proteins. The concentration used for further experiments was always $150 \mathrm{ng} / \mu \mathrm{L}$. cDNA was synthesized using Transcriba Kit (A\&A Biotechnology, Gdynia, Poland).

Amplification of gene specific primers (ABCB1, ABCC1, ABCG2; Table 1) was performed using Real-Time 2x-PCR SYBR Master Mix (A\&A Biotechnology, Gdynia, Poland) in Stratagene MX3005P QPCR System (Agilent Technologies, Inc. Santa Clara, CA, USA) according to the manufacturer's instructions. GAPDH was used as an internal reference gene to normalize the expression of investigated genes. The expression levels of the tested genes were determined by the $2^{-\Delta \Delta \mathrm{CT}}$ method [30].

\section{Assessment of $A B C B 1, A B C C 1$ and $A B C G 2$ protein levels by ELISA-based method}

The ABCB1, ABCC1 and ABCG2 protein levels in HL-60 and HL-60/5FU cells incubated with the tested compounds were measured by the ELISA-based method using ABCB1, ABCC1 and ABCG2 ELISA Kits. Briefly, cells were seeded on 6-well plates ( $4 \times 10^{5}$ cells/well) and incubated with the tested compounds at $\mathrm{IC}_{50}$ concentration each for $24 \mathrm{~h}$. The cells were washed with phosphate-buffered saline (PBS) and collected by centrifugation $(200 \times g, 5 \mathrm{~min})$. Cellular protein extracts were prepared using Protein Extract Kit (Active Motif, Carlsbad, CA, USA). Properly diluted cellular protein extracts $(25 \mu \mathrm{g})$ and standards were added into each well of 96-well plates pre-coated with ABCB1, ABCC1 and $\mathrm{ABCG} 2$ specific antibodies. $\mathrm{ABC}$ transporter proteins present in the tested samples specifically bound to the wells by immobilized antibodies. Addition of a secondary antibody conjugated to horseradish peroxidase (HRP) provided sensitive colorimetric readout. Finally, the stop solution was added to each well. The optical density (OD) of the yellow solution was measured spectrometrically at the wavelength of $450 \mathrm{~nm}$.

\section{ATPase assay}

The ATPase activity was measured using the ATP/ADP Luminescent Detection Assay, according to the manufacturer guidelines. Briefly, HL-60 and HL-60/5FU cells were
Table 1 Primer sequences for RT-PCR reaction

\begin{tabular}{lll}
\hline Gene & Primer sequences & \\
\cline { 2 - 3 } & Forward primer & Reverse primer \\
\hline GAPDH & GTCGCTGTTGAAGTCAGAGGAG & CGTGTCAGTGGTGGACCTGAC \\
$A B C B 1$ & GTGGGGCAAGTCAGTTCATT & TCTTCACCTCCAGGCTCAGT \\
$A B C C 1$ & AACAGGGCAGCAAACAGAAC & CATTCGAGCCTTCGAGGAG \\
$A B C G 2$ & GCTTTCTACCTGCACGAAAACCAGTTGAG & ATGGCGTTGAGACCAG \\
\hline
\end{tabular}


seeded on 96 -well plates at the density $1.0 \times 10^{4} / \mathrm{mL}$ in $100 \mu \mathrm{L}$ of standard growth medium and incubated with the tested compounds (at $\mathrm{IC}_{50}$ concentration) for $24 \mathrm{~h}$. To assess ATPase inhibition, HL-60/5FU cells were co-incubated with the tested compounds and 5-FU (at $\mathrm{IC}_{50}$ concentration each).

After incubation, $100 \mu \mathrm{L}$ of ADP-Glo day reagent was added. Each plate was shaken for $2 \mathrm{~min}$ on an orbital shaker and left at room temperature for $40 \mathrm{~min}$ for stabilization. Then, the detection reagent was added to each well. The luminescence signal was quantified using Flexstation 3 . The effects of the combination treatment were compared with those produced by the tested compounds alone.

\section{Results}

\section{Establishment of 5FU-resistant HL-60 cell line}

HL-60 cells were selected for 5-FU-resistant phenotype by a long-time exposure ( 3 months) of cells to increasing 5-FU concentrations, until the cells were able to tolerate the drug up to $0.08 \mathrm{mmol} / \mathrm{L}$ and proliferate normally.

The development of the drug resistant phenotype is always accompanied by changes in various biological features of the malignant cells, including morphological ones. When compared with HL-60, HL-60/5FU cells were larger with less defined irregular, rounded shape and contained multiple nucleoli in the cytoplasm. HL-60/5FU cells treated with 5-FU had more elongated shape as compared with the untreated ones but preserved membrane integrity (Fig. 3). It was also observed that HL-60/5FU showed faster growth rate (proliferation) than HL-60.

\section{Sensitivity of HL-60/5FU cells to 5FU}

According to the MTT assay results, the HL-60/5FU cells exhibited considerable resistance to 5-FU as compared with HL-60 cells, with the $\mathrm{IC}_{50}$ values $505 \mu \mathrm{M}$ and $82.5 \mu \mathrm{M}$, respectively (Fig. 4). The degree of resistance is usually evaluated in terms of resistance index $(\mathrm{R})$ which is calculated as $\mathrm{R}=\mathrm{IC}_{50}$ resistant cells $/ \mathrm{IC}_{50}$ sensitive cells. Therefore, the

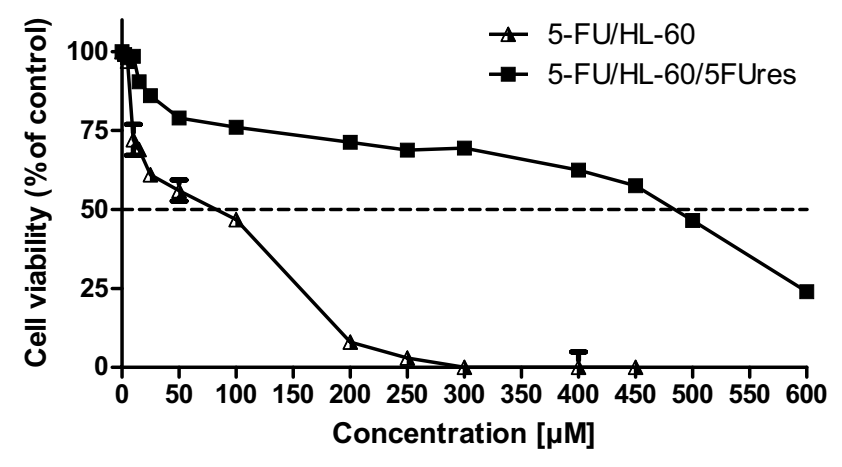

Fig. 4 The cytotoxic effect of 5-FU in HL-60 and HL-60/5FU cells analyzed by MTT assay

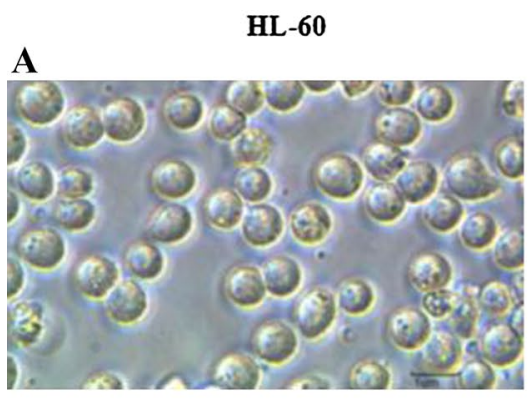

B

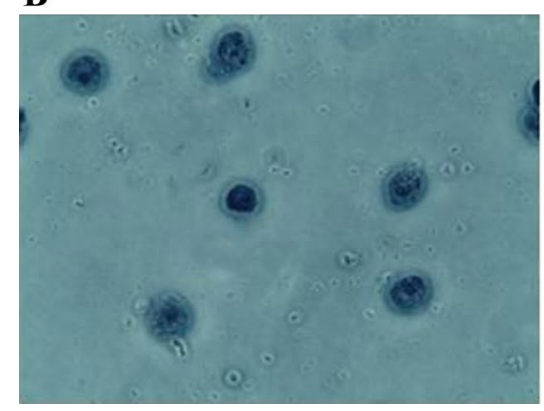

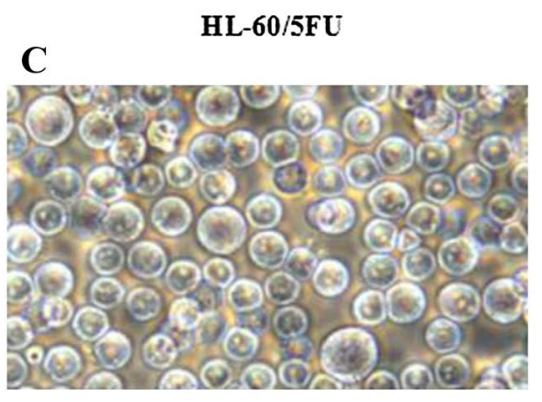

D

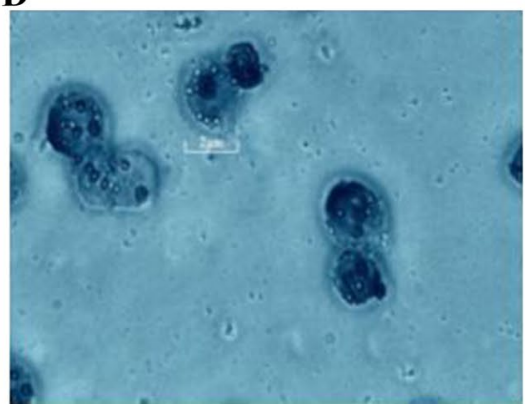

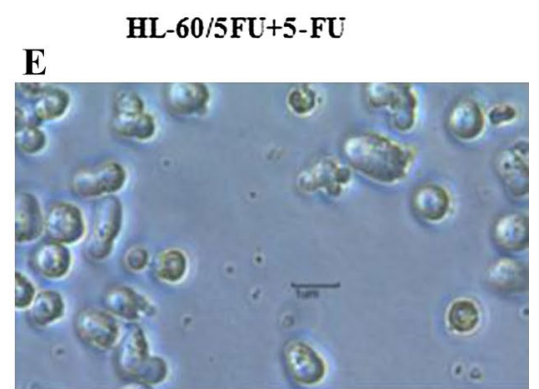

F

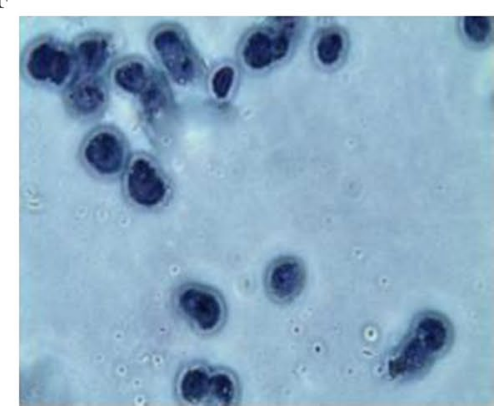

Fig. 3 Morphological changes in 5-FU-resistant cells. Morphological changes were examined by light microscopy in: a, b sensitive HL-60 cells; c, d HL-60/5FU cells; e, f HL-60/5FU cells incubated with the
5-FU at $\mathrm{IC}_{50}$ concentration for $24 \mathrm{~h}$. Cells were stained with WrightGiemsa stain (original magnification, $\times 1000$ ) 
Table 2 Cytotoxic activity of 1, 3-disubstituted 5-methylidenedihydrouracil analogs and 5-FU in HL-60/5FU cell line

\begin{tabular}{lrllr}
\hline Cancer cell & \multicolumn{4}{l}{$\mathrm{IC}_{50}$ values $(\mu \mathrm{M})$} \\
\cline { 2 - 5 } line & \multicolumn{1}{l}{$\mathrm{U}-236$} & $\mathrm{U}-332$ & $\mathrm{U}-259$ & \multicolumn{1}{c}{ 5-FU } \\
\hline HL-60 & $7.21 \pm 0.11$ & $0.94 \pm 0.01$ & $3.81 \pm 0.81$ & $82.54 \pm 0.91$ \\
HL-60/5FU & $10.12 \pm 0.21$ & $1.11 \pm 0.01$ & $4.31 \pm 0.91$ & $505.12 \pm 9.01$ \\
\hline
\end{tabular}

HL-60/5FU cells were approximately sixfold more resistant to 5 -FU than the original cell line.

\section{Sensitivity of HL-60/5FU cells to uracil analogs}

Cytotoxic activity of uracil analogs U-236, U-332 and U-359 in HL-60 and HL-60/5FU cells was compared in the MTT assay. As shown in Table 2 cytotoxic activities expressed as $\mathrm{IC}_{50}$ values were almost identical for U-332 and U-359 in both cell lines and differed only slightly for U-236, revealing that all three analogs were almost equally cytotoxic for HL-60 and HL-60/5FU cells.

\section{Gene expression alterations in 5FU resistant cells treated with uracil analogs}

The expression levels and the ${ }^{-\Delta \Delta} \mathrm{Ct}$ log-fold-change of $\mathrm{ABC}$ transporters were analyzed by quantitative RT-PCR.

In HL-60/5FU cells tolerant to 5-FU, relative $A B C B 1$, $A B C C 1, A B C G 2$ mRNA expression levels were 8.9-, 13.9and 8.6-fold higher than in sensitive HL-60 cells, respectively, as determined by RT-PCR (Table 3). 5FU only slightly up-regulated expression of these transporter genes in the sensitive HL-60 cells (1.2-, 1.7- and 3.7-fold, respectively) as compared with controls. In the resistant cells treated with 5-FU moderate enhancement of $A B C B 1$ and $A B C G 2$ expression was observed (6.68 and 5.09, respectively), while the mRNA level of $A B C C 1$ increased over 31-fold.

In the sensitive and resistant cell lines uracil analogs U-236, U-332, 359 (used at $\mathrm{IC}_{50}$ concentration each) moderately and similarly (1.2- to 5-fold) down-regulated transporter gene levels. Then, resistant cells were co-incubated with 5-FU and each of the analogs. U-332 in combination with 5-FU drastically down-regulated mRNA expression of $A B C C 1$, while the effect produced by the other two analogs was less pronounced.

\section{Assessment of $A B C B 1, A B C C 1$ and $A B C G 2$ protein level in HL-60 and HL-60/5FU cell lines}

To measure $\mathrm{ABCB} 1, \mathrm{ABCC} 1$ and $\mathrm{ABCG} 2$ protein concentration in cancer cell lysates, human $\mathrm{ABC}$ ELISA kits were used. Cancer cell lysates were prepared after $24 \mathrm{~h}$ exposure
Table 3 Expression of $\mathrm{ABC}$ transporter genes involved in multidrug resistance in HL-60 and HL-60/5FU cells treated with uracil analogs or 5-FU

\begin{tabular}{|c|c|c|c|}
\hline Gene & $A B C B 1$ & $A B C C 1$ & $A B C G 2$ \\
\hline \multicolumn{4}{|l|}{ HL-60 } \\
\hline Control & $1.0 \pm 0.011$ & $1.0 \pm 0.01$ & $1.0 \pm 0.01$ \\
\hline $5-\mathrm{FU}$ & $1.2 \pm 0.03$ & $1.7 \pm 0.05^{* * *}$ & $3.7 \pm 0.01 * * *$ \\
\hline Control & $1.0 \pm 0.02$ & $1.0 \pm 0.01$ & $1.0 \pm 0.01$ \\
\hline U-236 & $0.7 \pm 0.01 * *$ & $0.2 \pm 0.01$ & $0.8 \pm 0.08$ \\
\hline Control & $1.0 \pm 0.25$ & $1.0 \pm 0.33$ & $1.0 \pm 0.22$ \\
\hline U-332 & $0.2 \pm 0.002 * * *$ & $0.1 \pm 0.001 * * *$ & $0.4 \pm 0.001 * *$ \\
\hline Control & $1.0 \pm 0.011$ & $1.0 \pm 0.01$ & $1.0 \pm 0.01$ \\
\hline U-359 & $0.2 \pm 0.008 *$ & $0.6 \pm 0.009 * *$ & $0.3 \pm 0.009 * *$ \\
\hline \multicolumn{4}{|c|}{ HL-60/5FU } \\
\hline Control & $1.0 \pm 0.22$ & $1.0 \pm 0.03$ & $1.0 \pm 0.003$ \\
\hline 5-FU & $6.68 \pm 1.04 * *, \# \#$ & $31.02 \pm 4.23 * * *, \# \#$ & $5.09 \pm 0.01 * * *$ \\
\hline Control & $1.0 \pm 0.001$ & $1.0 \pm 0.01$ & $1.0 \pm 0.01$ \\
\hline U-236 & $0.8 \pm 0.01^{*,+++}$ & $0.1 \pm 0.02 * * *,+++$ & $0.8 \pm 0.02^{*,+++}$ \\
\hline Control & $1.0 \pm 0.01$ & $1.0 \pm 0.01$ & $1.0 \pm 0.01$ \\
\hline U-332 & $0.2 \pm 0.01 * *,+++$ & $0.1 \pm 0.01 * * *,+++$ & $0.3 \pm 0.01 * *+++$ \\
\hline Control & $1.0 \pm 0.02$ & $1.0 \pm 0.01$ & $1.0 \pm 0.07$ \\
\hline U-359 & $0.2 \pm 0.003 * *,+++$ & $0.6 \pm 0.001 * * *,+++$ & $0.3 \pm 0.002^{* *,+++}$ \\
\hline \multicolumn{4}{|c|}{ HL-60/5FU (co-incubation with 5-FU) } \\
\hline Control & $1.0 \pm 0.02$ & $1.0 \pm 0.03$ & $1.0 \pm 0.02$ \\
\hline U-236 & $1.1 \pm 0.01$ & $0.7 \pm 0.01$ & $0.9 \pm 0.01 * * *$ \\
\hline Control & $1.0 \pm 0.01$ & $1.0 \pm 0.08$ & $1.0 \pm 0.23$ \\
\hline U-332 & $0.4 \pm 0.01 * *$ & $0.1 \pm 0.01 * * *$ & $0.6 \pm 0.01 * *$ \\
\hline Control & $1.0 \pm 0.02$ & $1.0 \pm 0.22$ & $1.0 \pm 0.07$ \\
\hline U-359 & $0.5 \pm 0.03^{* *}$ & $0.4 \pm 0.01 * * *$ & $0.9 \pm 0.01$ \\
\hline
\end{tabular}

Data are presented as mean \pm SEM. Statistical significance was assessed by the test $t * p<0.05 ; * * p<0.01 ; * * * p<0.001$ in comparison with control and ${ }^{++} p<0.001$ in comparison with $5-\mathrm{FU}$ (in HL$60 / 5 \mathrm{FU}$ cells), ${ }^{\# \#} p<0.01$; \#\#\# $p<0.001$ in comparison with $5-\mathrm{FU}$ (in HL-60 cells)

of cells to uracil analogs alone or with 5-FU (at $\mathrm{IC}_{50}$ concentration each). The effects of the concomitant treatments were compared with those produced by $5-\mathrm{FU}$ or with the analogs alone.

Consistent with enhanced gene expression, 5-FU significantly up-regulated protein levels of all three transporters in both cell lines (Fig. 5). On the other hand, uracil analogs down-regulated the level of ABCB1, ABCC1 and ABCG2 in HL-60, as well as in HL-60/5FU cells, with the strongest effect observed for U-332. Co-incubation of U-236, U-332 or U-359 with 5-FU potently decreased protein levels of $\mathrm{ABCB} 1, \mathrm{ABCC} 1$ and $\mathrm{ABCG} 2$ in the resistant cells, with the strongest change observed for $\mathrm{ABCC} 1$. The effect produced by U-332 was even below the value obtained for the untreated cells and was close to zero. U-332 can be therefore considered a new efficient inhibitor/downregulator of $\mathrm{ABCC} 1$ transporter. 

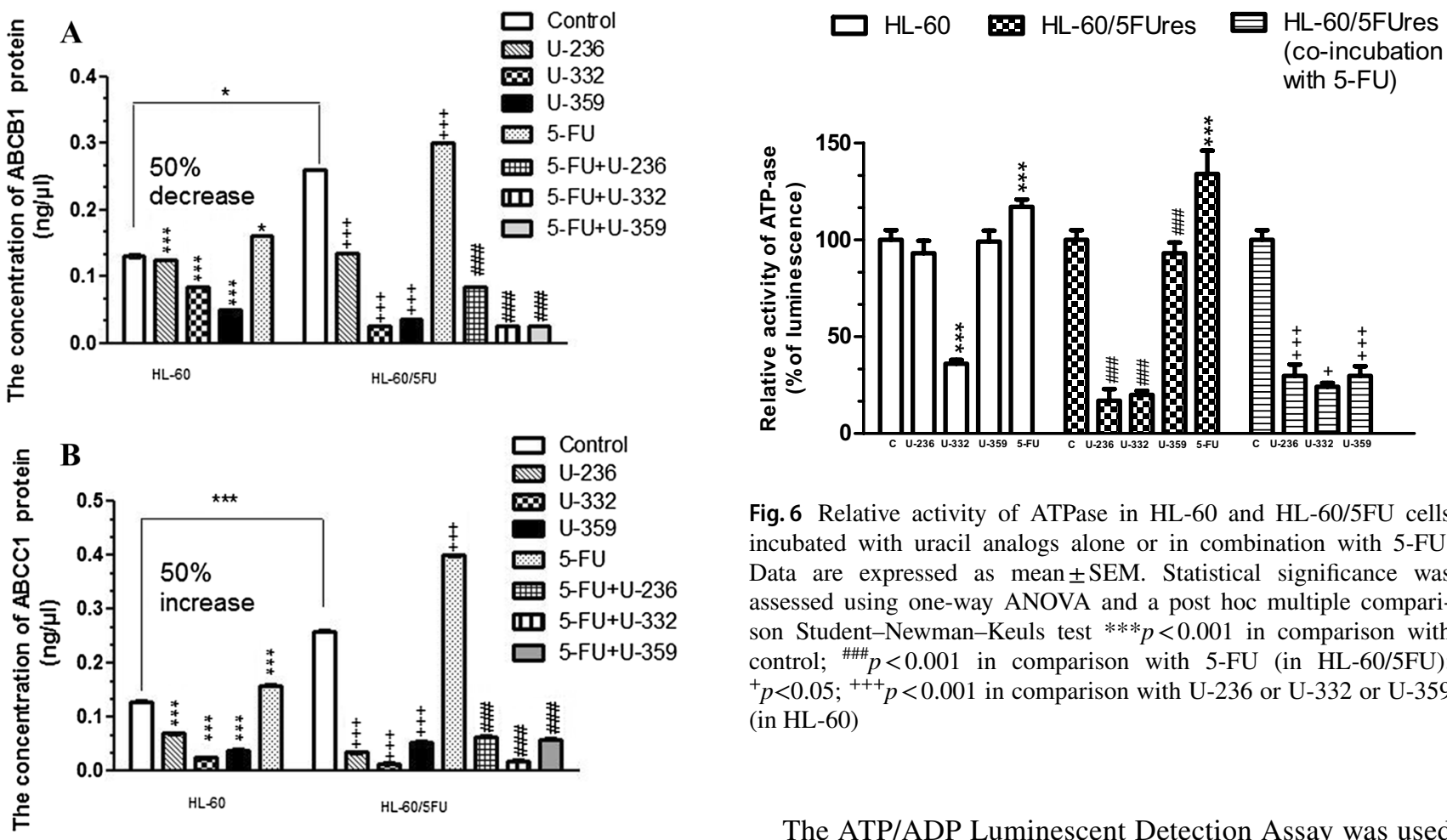

Fig. 6 Relative activity of ATPase in HL-60 and HL-60/5FU cells incubated with uracil analogs alone or in combination with 5-FU. Data are expressed as mean \pm SEM. Statistical significance was assessed using one-way ANOVA and a post hoc multiple comparison Student-Newman-Keuls test $* * * p<0.001$ in comparison with control; \#\#\# ${ }^{2} 0.001$ in comparison with 5 -FU (in HL-60/5FU); ${ }^{+} p<0.05 ;{ }^{+++} p<0.001$ in comparison with U-236 or U-332 or U-359 (in HL-60)

The ATP/ADP Luminescent Detection Assay was used to determine the level of ATPase activity in HL-60 and HL$60 / 5 \mathrm{FU}$ cells incubated with uracil analogs alone or in combination with 5-FU.

In HL-60 cells U-332 decreased the relative activity of ATPase to $36 \%$, while the results obtained for U-236 and U-359 were non-significant (Fig. 6). The inhibition of ATP hydrolysis was much stronger in HL-60/5FU cells. The incubation of these cells with U-236, U-332 and U-359 caused a decrease of ATPase activity to $20 \%, 17 \%$ and $93 \%$, respectively, as compared with control. By contrast, both HL-60 and HL-60/5FU cells treated with 5-FU had significantly increased ATPase activity, up to $117 \%$ and $134 \%$, respectively.

Co-incubation of cells with U-236, U-332 or U-359 and

Fig. 5 Influence of U-236, U-332, U-359 and 5-FU on ABCB1 (a) $\mathrm{ABCC} 1$ (b) and ABCG2 (c) protein concentration in HL-60 and HL60/5FU cells. Human ABC ELISA kits and extracts from cancer cells treated with the analogs and 5-FU (at $\mathrm{IC}_{50}$ concentration each) were used. Data are expressed as mean \pm SEM. Statistical significance was assessed using one-way ANOVA and a post hoc multiple comparison Student-Newman-Keuls test. ${ }^{*} p<0.05 ; * * * p<0.001$ in comparison with control; ${ }^{+++} p<0.001$ in comparison with 5 -FU (in HL-60/5FU); ${ }^{\# \# \# p} p<0.001$ in comparison with U-236 or U-332 or U-359 (in HL-60)

\section{Modulation of ABC transporter-mediated ATP hydrolysis by uracil analogs}

$\mathrm{ABC}$ transporters mediate the transport of substrates against a concentration gradient using energy derived from ATP hydrolysis, which is proportional to the transporter activity and could easily be detected by a luminescence method. Measuring ATPase activity allows for the assessment of $\mathrm{ABC}$ transporter levels [31-33]. 5 -FU powerfully decreased the relative activity of ATPase, to $29 \%$ (for U-236 and U-359) and 24\% (for U-332), compared with the effects produced by 5 -FU alone.

\section{Discussion}

The appearance of the MDR phenotype is a major and still unresolved problem in the therapy of leukemia. Cancer cells may either possess inherent resistance to some drugs or can become resistant after cycles of chemotherapy (acquired resistance). Numerous studies have shown that drug-resistance can be linked to enhanced efflux of various drugs from cancer cells by $\mathrm{ABC}$ transporters [34]. The major anticancer drugs such as doxorubicin, mitoxantrone, etoposide, topotecan, 5-FU are all substrates for the ABC transporters, usually 
overexpressed in tumor cells and the delivery of these drugs to the site of action is often very limited if not impossible [35-37].

For this reason, a lot of research have been focused on identifying inhibitors/downregulators of $\mathrm{ABC}$ transporters [38-40]. Such compounds may affect drug transport in several ways. They can directly interact with $\mathrm{ABC}$ transporter proteins, decrease the level of intracellular ATP which is the source of energy for the ABC pumps, they can influence membrane phospholipids, increasing membrane permeability for ions that reduce activity of these transporters [41]. Such inhibitors/downregulators, used in combination with known anticancer drugs can improve drugs' efficacy and suppress resistance.

The first generation of inhibitors, also referred to as chemosensitizers, such as verapamil, calmodulin antagonists or indol alkaloids, was characterized by low activity which required the use of high doses and therefore resulted in elevated toxicity $[38,42]$. Agents of the second generation, such as cyclosporin A, GF120918 (elacridar) and dexverapamil had less side effects but still low affinity for ABC transporters, as they were also substrates for cytochrome P450 and were quickly metabolized by this enzyme [43]. Inhibitors of the third-generation were designed to specifically inhibit activity of only one transporter, in most cases ABCB1, and some of them are currently in various stages of clinical trials $[44,45]$. Examples of such agents are laniquidar, anthranilamide derivative tariquidar and pipecolinate analog biricodar [46]. Despite their diverse chemical structures they all have high potency and specificity for ABCB1 transporter. The fourth-generation inhibitors include various classes of natural compounds belonging to many chemical families, such as alkaloids, flavonoids, coumarins, terpenoids. These compounds offer a potential for semi-synthetic modifications to produce new scaffolds which may evade the toxicities shown by currently used inhibitors [46, 47]. Some of these compounds are inhibitors of $\mathrm{ABCC} 1$ and ABCG2 (hydrophobic flavones, acridones, chromanones) but they are still in the phase of in vitro studies [48].

In this report we tested three novel synthetic 5-methylidenedihydrouracil analogs which significantly inhibited proliferation in HL-60 cells, as potential expression modulators of $\mathrm{ABCB} 1, \mathrm{ABCC} 1$ and $\mathrm{ABCG} 2$ proteins, considered responsible for anticancer drug insensitivity in leukemic cells.

The 5-FU resistant subline was obtained from the HL-60 cell line by the conventional method of intermittent and continuous exposure of the cells to 5-FU. This subclone was reproducible and the cells were sixfold more resistant to 5-FU in the MTT assay compared with the parental cells.

In the resistant cells treated with 5-FU expression of the three mentioned above transporters was up-regulated but the highest increase (over 30-fold) was observed for ABCC1. We have also shown that in the HL-60/5FU cells relative ABCB1, $\mathrm{ABCC} 1$ and $\mathrm{ABCG} 2$ protein levels were twofold higher than in the sensitive HL-60 cells, indicating that 5-FU was probably a substrate for these transporters.

Three new synthetic 5-methylidenedihydrouracil analogs, U-236, U-332 and U-359, highly cytotoxic for HL-60 cells in MTT test, showed similar cytotoxicity also in the resistant cell line. These analogs were then evaluated as possible inhibitors/ downregulators of $\mathrm{ABCB} 1, \mathrm{ABCC} 1$ and $\mathrm{ABCG} 2$ transporters in HL-60/5FU cell line. All three compounds, but most significantly U-332, were able to reverse resistance of HL-60/5FU cells to 5-FU treatment.

To confirm the substrate or inhibitor nature of 5-FU and the analogs, their influence on the ATPase activity was then investigated. As opposed to 5-FU which stimulated ATPase activity, being therefore a substrate for the transporters, U-332 significantly inhibited the ATP hydrolysis in both tested cell lines. Co-incubation of HL-60/5FU cells with U-332 and 5-FU powerfully down-regulated the relative activity of ATPase, confirming that this analog could decrease the activity of $\mathrm{ABC}$ transporters in HL-6-/5FU cells.

In conclusion, in the present study the leukemia 5-FUselected HL-60 cell line with multidrug resistance characteristics was established. These characteristics included overexpression of $\mathrm{ABCB} 1, \mathrm{ABCG} 2$ and $\mathrm{ABCC} 1$ transporters, indicating that their high level is responsible for drug resistance. Out of these three transporters, $\mathrm{ABCC} 1$ was found to be the most overexpressed. The synthetic uracil analog U-332 potently decreased the level of $\mathrm{ABCC} 1$ protein in the resistant cells and can be considered an efficient inhibitor/downregulator of this transporter in cancer cells.

Acknowledgements The present study was supported by grant Preludium No DEC-2017/25/N/NZ3/01039 to A.D-P from the National Science Center (NCN).

Author contributions Research design and conducting experiments: AD-P. Designing, synthesis and analytical characterization of new analogs: MP and TJ. Writing the manuscript: AD-P and AJ.

\section{Compliance with ethical standards}

Conflict of interests The author(s) declare no competing interests.

Open Access This article is distributed under the terms of the Creative Commons Attribution 4.0 International License (http://creativeco mmons.org/licenses/by/4.0/), which permits unrestricted use, distribution, and reproduction in any medium, provided you give appropriate credit to the original author(s) and the source, provide a link to the Creative Commons license, and indicate if changes were made. 


\section{References}

1. Grove CS, Vassiliou GS (2014) Acute myeloid leukaemia: a paradigm for the clonal evolution of cancer? Dis Model Mech 7:941-951

2. Zhang J, Gu Y, Chen B (2019) Mechanisms of drug resistance in acute myeloid leukemia. OncoTargets Ther 12:1937

3. Sonneveld P, Suciu S, Weijermans P, Beksaç M, Neuwirtova R, Solbu G, Segeren CM (2001) Cyclosporin A combined with vincristine, doxorubicin and dexamethasone (VAD) compared with VAD alone in patients with advanced refractory multiple myeloma: an EORTC-HOVON randomized phase III study (06914). Brit J Haematol 115:895-902

4. Liu FS (2009) Mechanisms of chemotherapeutic drug resistance in cancer therapy-a quick review. Taiwan J Obstet Gynecol 48:239-244

5. Mansoori B, Mohammadi A, Davudian S, Shirjang S, Baradaran B (2017) The different mechanisms of cancer drug resistance: a brief review. APB 7:339

6. Długosz A, Janecka A (2016) ABC transporters in the development of multidrug resistance in cancer therapy. Curr Pharm Design 22:4705-4716

7. Gottesman MM, Ambudkar SV (2001) Overview: ABC transporters and human disease. J Bioenerg Biomembr 33:453-458

8. Dean M, Annilo T (2005) Evolution of the ATP-binding cassette $(\mathrm{ABC})$ transporter superfamily in vertebrates. Annu Rev Genom Hum Genet 6:123-142

9. de Figueiredo-Pontes LL, Pintão MCT, Oliveira LC, Dalmazzo LF, Jácomo RH, Garcia AB, Rego EM (2008) Determination of P-glycoprotein, MDR-related protein 1, breast cancer resistance protein, and lung-resistance protein expression in leukemic stem cells of acute myeloid leukemia. Cytom B 74:163-168

10. Chen J, Tian W, Cai H, He H, Deng Y (2009) Down-regulation of microRNA-200c is associated with drug resistance in human breast cancer. Med Oncol 29:2527-2534

11. Nakanishi T, Ross DD (2012) Breast cancer resistance protein (BCRP/ABCG2): its role in multidrug resistance and regulation of its gene expression. Chin J Cancer Res 31:73-99

12. Hooijberg JH, Broxterman HJ, Kool M, Assaraf YG, Peters GJ, Noordhuis P, Scheper RJ, Borst P, Pinedo HM, Jansenl G (1999) Antifolate resistance mediated by the multidrug resistance proteins MRP1 and MRP2. Cancer Res 59:2532-2535

13. van der Kolk DM, de Vries EG, van Putten WL, Verdonck LF, Ossenkoppele GJ, Verhoef GE, Vellenga E (2000) P-glycoprotein and multidrug resistance protein activities in relation to treatment outcome in acute myeloid leukemia. Clin Cancer Res 6:3205-3214

14. Dean $M$ (2009) ABC transporters, drug resistance, and cancer stem cells. J Mammary Gland Biol Neoplasia 14:3-9

15. Paszel-Jaworska A, Rubiś B, Bednarczyk-Cwynar B, Zaprutko L, Rybczyńska M (2015) Proapoptotic activity and ABCC1related multidrug resistance reduction ability of semisynthetic oleanolic acid derivatives DIOXOL and HIMOXOL in human acute promyelocytic leukemia cells. Chem Biol Interact 242:1-12

16. Cao D, Qin S, Mu Y, Zhong M (2017) The role of MRP1 in the multidrug resistance of colorectal cancer. Oncol Lett 13:2471-2476

17. Cai BL, Xu XF, Fu SM, Shen LL, Zhang J, Guan M, Wu JZ (2011) Nuclear translocation of MRP1 contributes to multidrug resistance of mucoepidermoid carcinoma. Oral Oncol 47:1134-1140

18. Noordhuis P, Holwerda U, Van der Wilt CL, Van Groeningen CJ, Smid K, Meijer S, Peters GJ (2004) 5-Fluorouracil incorporation into RNA and DNA in relation to thymidylate synthase inhibition of human colorectal cancers. Ann Oncol 15:1025-1032
19. de la Cueva A, de Molina AR, Álvarez-Ayerza N, Ramos MA, Cebrián A, del Pulgar TG, Lacal JC (2013) Combined 5-FU and ChoK $\alpha$ inhibitors as a new alternative therapy of colorectal cancer: evidence in human tumor-derived cell lines and mouse xenografts. PLoS ONE 8:e64961-e64974

20. Focaccetti C, Bruno A, Magnani E, Bartolini D, Principi E, Dallaglio K, Albini A (2015) Effects of 5-fluorouracil on morphology, cell cycle, proliferation, apoptosis, autophagy and ROS production in endothelial cells and cardiomyocytes. PLoS ONE 10:e0115686-e0115698

21. Gao K, Liang Q, Zhao ZH, Li YF, Wang SF (2016) Synergistic anticancer properties of docosahexaenoic acid and 5-fluorouracil through interference with energy metabolism and cell cycle arrest in human gastric cancer cell line AGS cells. World J Gastroenterol 22:2971-2980

22. Tamaki A, Ierano C, Szakacs G, Robey RW, Bates SE (2011) The controversial role of $\mathrm{ABC}$ transporters in clinical oncology. Essays Biochem 50:209-232

23. Gomtsyan A (2012) Heterocycles in drugs and drug discovery. Chem Heterocycl Compd 48:7-10

24. Vitaku E, Smith DT, Njardarson JT (2014) Analysis of the structural diversity, substitution patterns, and frequency of nitrogen heterocycles among US FDA approved pharmaceuticals: miniperspective. J Med Chem 57:10257-10274

25. Mondal D, Koehn EM, Yao J, Wiemer DF, Kohen A (2018) Chemo-enzymatic synthesis of the exocyclic olefin isomer of thymidine monophosphate. Bioorg Med Chem 26:2365-2371

26. Du ZX, Zhang HY, Meng X, Guan Y, Wang HQ (2009) Role of oxidative stress and intracellular glutathione in the sensitivity to apoptosis induced by proteasome inhibitor in thyroid cancer cells. BMC Cancer 9:56

27. Drozd E, Gruber B, Marczewska J, Drozd J, Anuszewska E (2016) Intracellular glutathione level and efflux in human melanoma and cervical cancer cells differing in doxorubicin resistance. Postepy Hig Med Dosw 70:319-328

28. Pięta M, Kędzia J, Kowalczyk D, Wojciechowski J, Wolf WM, Janecki T (2019) Enantioselective synthesis of 5-methylidenedihydrouracils as potential anticancer agents. Tetrahedron 75:2495-2505

29. Mosmann T (1983) Rapid colorimetric assay for cellular growth and survival: application to proliferation and cytotoxicity assays. J Immunol Methods 65:55-63

30. Winer J, Jung CK, Shackel I, Williams P (1999) Development and validation of real-time quantitative reverse transcriptasepolymerase chain reaction for monitoring gene expression in cardiac myocytes in vitro. Anal Biochem 15:41-49

31. Nervi P, Li-Blatter X, Äänismaa P, Seelig A (2010) P-glycoprotein substrate transport assessed by comparing cellular and vesicular ATPase activity. BBA-Biomembranes 1798:515-525

32. Kimura Y, Kioka N, Kato H, Matsuo M, Ueda K (2007) Modulation of drug-stimulated ATPase activity of human MDR1/Pglycoprotein by cholesterol. Biochem J 401:597-605

33. Glavinas H, Kis E, Pal A, Kovacs R, Jani M, Vagi E, Bathori G (2007) ABCG2 (BCRP/MXR) ATPase assay-a useful tool to detect drug-transporter interactions. Drug Met Disp. https://doi. org/10.1124/dmd.106.014605

34. Lopes-Rodrigues V, Di Luca A, Mleczko J, Meleady P, Henry M, Pesi M, Falcon-Perez JM (2017) Identification of the metabolic alterations associated with the multidrug resistant phenotype in cancer and their intercellular transfer mediated by extracellular vesicles. Sci Rep-UK 7:44541-44580

35. Honorat M, Falson P, Terreux R, Di Pietro A, Dumontet C, Payen L (2011) Multidrug resistance ABC transporter structure predictions by homology modeling approaches. Curr Drug Metab 12:268-277 
36. Au A, Baba AA, Azlan H, Norsa' adah B, Ankathil R (2014) Clinical impact of $\mathrm{ABCC} 1$ and $\mathrm{ABCC} 2$ genotypes and haplotypes in mediatingimatinib resistance among chronic myeloid leukaemia patients. J Clin Pharm Ther 39:685-690

37. Lewinson O, Livnat-Levanon N (2017) Mechanism of action of $\mathrm{ABC}$ importers: conservation, divergence, and physiological adaptations. J Mol Biol 429:606-619

38. Patel A, Li TW, Anreddy N, Wang DS, Sodani K, Gadhia S, Chen ZS (2017) Suppression of ABCG2 mediated MDR in vitro and in vivo by a novel inhibitor of ABCG2 drug transport. Pharmacol Res 121:184-193

39. Cole SP (2014) Multidrug resistance protein 1 (MRP1, ABCC1), a "multitasking" ATP-binding cassette (ABC) transporter. J Biol Chem 289:30880-30888

40. Li L, Xiao-Dong L (2014) Alterations in function and expression of $\mathrm{ABC}$ transporters at blood-brain barrier under diabetes and the clinical significances. Front Pharmacol 5:273-282

41. Sharom FJ (2014) Complex interplay between the P-glycoprotein multidrug efflux pump and the membrane: its role in modulating protein function. Front Oncol 4:41-60

42. Mruk DD, Su L, Cheng CY (2011) Emerging role for drug transporters AT the blood-testis barier. Trends Pharmacol Sci 32:99-106

43. Amin ML (2013) P-glycoprotein inhibition for optimal drug delivery. Drug Target Insights 7:27-34
44. Thomas H, Coley HM (2003) Overcoming multidrug resistance in cancer: an update on the clinical strategy of inhibiting p-glycoprotein. Cancer Control 10:159-165

45. Saraswathy M, Gong S (2013) Different strategies to overcome multidrug resistance in cancer. Biotechnol Adv 31:1397-1407

46. Ozben T (2006) Mechanisms and strategies to overcome multiple drug resistance in cancer. FEBS Lett 580:2903-2909

47. Genovese I, Ilari A, Assaraf YG, Fazi F, Colotti G (2017) Not only P-glycoprotein: amplification of the ABCB1-containing chromosome region $7 \mathrm{q} 21$ confers multidrug resistance upon cancer cells by coordinated overexpression of an assortment of resistancerelated proteins. Drug Resist Update 32:23-46

48. Gozzi GJ, Bouaziz Z, Winter E, Daflon-Yunes N, Honorat M, Guragossian N, Pinaud N (2015) Phenolic indeno [1, 2-b] indoles as ABCG2-selective potent and non-toxic inhibitors stimulating basal ATPase activity. Drug Des Dev Ther 9:3481-3493

Publisher's Note Springer Nature remains neutral with regard to jurisdictional claims in published maps and institutional affiliations. 